\title{
Activation Antigens of Lymphocytes in Patients With Atopic Diseases
}

\author{
Alexander Kazimirskii*, Jean Salmasi, Gennady Poryadin, Lyudmila Semenova, Oxana Tutcheva and \\ Nadezhda Khamnagdayeva \\ Department of Patophysiology and Clinical Patophysiology, RNRMU, Ostrovityanova 1, Moscow, 117997, Russia
}

*Corresponding author: Kazimirskii AN, Department of Patophysiology and Clinical Patophysiology, RNRMU, Ostrovityanova 1, Moscow, 117997, Russia

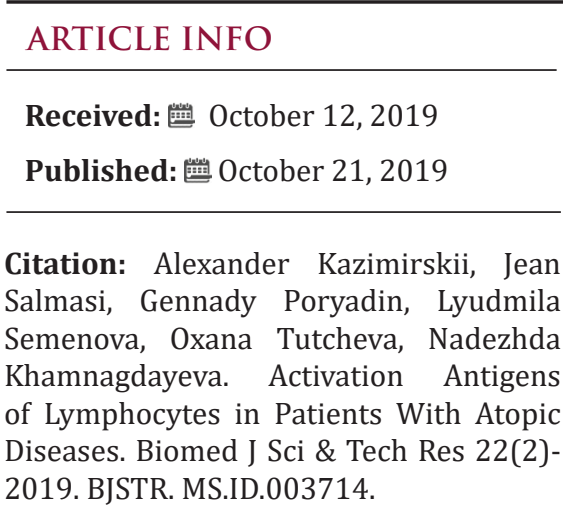

Keywords: Atopic Diseases; Lymphocyte Activation Antigens; Cd95; Apoptosis

\begin{abstract}
Aim: Study the expression of surface activation receptors on lymphocytes from patients with different forms of atopic diseases.

Methods: Determination of surface activation antigens of lymphocytes CD23, CD25, CD71, HLA-DR, CD95, CD178 and CD54, population and subpopulation antigens CD3, CD4, CD8, CD16, CD56, CD20, CD72, CD38, CD23, CD25, CD71, HLA-DR, CD95, CD54 and membrane immunoglobulins mIgM and mIgG using the method of indirect immunofluorescence using monoclonal antibodies (ICO, DACO, eBioscience). Samples of peripheral blood were obtained from 44 patients with atopic asthma and 36 patients with atopic dermatitis in the acute phase of the disease. The control group included 26 healthy people.
\end{abstract}

Results: The results obtained show that atopic diseases have not only various clinical manifestations, but also the various mechanisms of the disorders of the immune system. The development of atopic asthma and atopic dermatitis is accompanied by an additional increase in the expression the late activation marker HLA-DR, a marker of precursors of plasma cells (CD38) and lymphocytes bearing surface immunoglobulins in the peripheral blood of patients. In the blood of patients with severe clinical manifestations of atopy was found significant increase in the number of all investigated subpopulations of B-lymphocytes. In patients with atopic bronchial asthma and atopic dermatitis blood CD95+ lymphocytes were reduced, and the number of CD178+lymphocytes was increased, reflecting to the violation of Fas-dependent apoptosis in severe atopic diseases.

Conclusion: In patients with severe atopic diseases, activation of lymphocyte apoptosis is impaired due to a weakened expression of the surface CD95 receptor of lymphocytes in the peripheral blood. We suggest that mir23a/b micro RNA is the most likely candidate for an inhibitor of CD95 expression.

\section{Introduction}

The most important trend in modern medicine is the transfer of the results of fundamental biomedical research into medical practice in order to improve treatment and diagnosis. Allergic diseases, which are based on impaired function of the immune system, are the most prevalent cause of disability in many industrialized countries. However, despite a long-term study of the pathogenesis of allergic diseases, the mechanisms of immune system restructuring remain unclear. A complete understanding the features of the immune system functioning in pathology, the study of the mechanisms of disease progression, the selection of optimal therapy can be obtained only with a comprehensive assessment of the functional state of various parts of the immune system.

One of the most effective methods is to evaluate the expression of individual functional molecules on the surface of lymphocytes. Using a wide range of monoclonal antibodies to surface lymphocyte receptors, it is possible to evaluate both quantitative (population and subpopulation) parameters and the functional state of the immune system. This approach makes it possible to study impaired 
activity of various subpopulations of lymphocytes and impaired apoptosis. For allergology, the concept of a personalized approach based on translational medicine can most effectively be realized in the study of diseases such as hay fever, bronchial asthma, atopic dermatitis [1-3].

\section{Methods}

We examined 44 patients with atopic bronchial asthma and 36 patients with atopic dermatitis. All patients with atopic bronchial asthma and atopic dermatitis were examined during the exacerbation of the disease. 26 healthy people were included to the control group. An assessment of the relative and absolute content of lymphocytes expressing the antigens CD3, CD4, CD8, CD16, CD56, CD20, CD72, CD38, CD23, CD25, CD71, HLA-DR, CD95, CD54, CD30, CD178 and membrane immunoglobulins mIgM and mIgG was assessed by indirect immunofluorescence method using monoclonal antibodies (ICO, DACO, eBioscience). As auxiliary methods used the selection of lymphocytes by the method of Boyum in density gradient ficoll-verografin, assess their viability immediately after isolation from peripheral blood. Statistical processing of the obtained results to assess the reliability of the recorded changes was conducted with a large sample, using the student's t-test for small sample with abnormal distribution, as well as when comparing pairwise - associated variant using a nonparametric criterion of Wilcoxon-Mann-Whitney.

\section{Results and Discussion}

The results of the studies are shown in Tables 1-4. Atopic bronchial asthma and atopic dermatitis are characterized by similar changes in the expression of surface lymphocyte receptors - markers of lymphocyte subpopulations [4-7]. In these diseases, an extensive inflammatory process was observed, accompanied by the synthesis of the so-called allergic cytokines IL-33 and TSLP (Thymic Stromal Lymphopoietin) [8], as well as the intensification of lipid peroxidation and the formation of their final products [9-11]. Our results allow us to summarize the changes in the population and subpopulation composition of peripheral blood lymphocytes in order to highlight the most characteristic changes.

Table 1: The content of subpopulations of T-lymphocytes and NK cells in the peripheral blood in patients with various forms of atopic diseases, $\mathrm{X} \pm \mathrm{m}$.

\begin{tabular}{|c|c|c|c|}
\hline $\begin{array}{c}\text { Antigens } \\
\text { markers }\end{array}$ & $\begin{array}{c}\text { Healthy } \\
\text { donors }\end{array}$ & $\begin{array}{c}\text { Atopic } \\
\text { bronchial } \\
\text { asthma }\end{array}$ & $\begin{array}{c}\text { Atopic } \\
\text { dermatitis }\end{array}$ \\
\hline $\mathrm{CD}^{+}$ & $66,74 \pm 0,99$ & $56,64 \pm 1,72^{* * *}$ & $59,03 \pm 1,53^{* *}$ \\
\hline $\mathrm{CD}^{+}$ & $36,71 \pm 1,26$ & $33,42 \pm 0,73^{* *}$ & $35,90 \pm 2,65$ \\
\hline $\mathrm{CD}^{+}$ & $26,34 \pm 0,75$ & $20,69 \pm 0,73^{* * *}$ & $21,79 \pm 1,33^{*}$ \\
\hline $\mathrm{CD}^{+} 6^{+}$ & $12,84 \pm 0,68$ & $9,73 \pm 0,33^{* * *}$ & $12,5 \pm 1,49$ \\
\hline $\mathrm{CD}^{+} 6^{+}$ & $4,78 \pm 0,52$ & $15,58 \pm 1,14^{* * *}$ & -- \\
\hline
\end{tabular}

Note: Here in after: * $(p<0.05),{ }^{* *}(p<0.01),{ }^{* * *}(p<0.01)$ compared with the group of healthy donors.
Table 2: Surface markers of B-lymphocytes in peripheral blood in patients with various forms of atopic diseases, $X \pm m$.

\begin{tabular}{|c|c|c|c|}
\hline $\begin{array}{c}\text { Antigens } \\
\text { markers }\end{array}$ & $\begin{array}{c}\text { Healthy } \\
\text { donors }\end{array}$ & $\begin{array}{c}\text { Atopic } \\
\text { bronchial } \\
\text { asthma }\end{array}$ & $\begin{array}{c}\text { Atopic } \\
\text { dermatitis }\end{array}$ \\
\hline $\mathrm{CD} 20^{+}$ & $9,97 \pm 0,42$ & $17,44 \pm 0,64^{* * *}$ & $19,75 \pm 1,71^{* * *}$ \\
\hline $\mathrm{CD}^{+} 2^{+}$ & $10,43 \pm 0,51$ & $15,67 \pm 0,56^{* * *}$ & $9,52 \pm 1,82$ \\
\hline $\mathrm{mIgM}^{+}$ & $5,98 \pm 0,39$ & $14,22 \pm 0,32^{* * *}$ & $13,51 \pm 1,39^{* * *}$ \\
\hline $\mathrm{mIgG}^{+}$ & $6,27 \pm 0,75$ & $14,17 \pm 0,31^{* * *}$ & $14,36 \pm 1,63^{* * *}$ \\
\hline $\mathrm{CD}^{*} 8^{+}$ & $7,33 \pm 0,52$ & $13,76 \pm 0,55^{* * *}$ & -- \\
\hline
\end{tabular}

Table 3: The content of lymphocytes expressing activation markers in peripheral blood in patients with various forms of atopic diseases, $\mathrm{X} \pm \mathrm{m}$.

\begin{tabular}{|c|c|c|c|}
\hline $\begin{array}{c}\text { Antigens } \\
\text { markers }\end{array}$ & $\begin{array}{c}\text { Healthy } \\
\text { donors }\end{array}$ & $\begin{array}{c}\text { Atopic } \\
\text { bronchial } \\
\text { asthma }\end{array}$ & $\begin{array}{c}\text { Atopic } \\
\text { dermatitis }\end{array}$ \\
\hline $\mathrm{CD} 3^{+}$ & $5,29 \pm 0,30$ & $13,26 \pm 0,36^{* * *}$ & $14,09 \pm 2,55^{* * *}$ \\
\hline $\mathrm{CD}^{+} 5^{+}$ & $6,04 \pm 0,24$ & $15,70 \pm 0,37^{* * *}$ & $13,37 \pm 1,34^{* * *}$ \\
\hline $\mathrm{CD}^{*} 1^{+}$ & $6,32 \pm 0,21$ & $13,11 \pm 0,77^{* * *}$ & $15,13 \pm 2,04^{* * *}$ \\
\hline $\mathrm{HLA}^{*} \mathrm{DR}^{+}$ & $11,83 \pm 0,30$ & $23,85 \pm 0,65^{* * *}$ & $20,11 \pm 1,69^{* *}$ \\
\hline $\mathrm{CD}^{+} 4^{+}$ & $5,55 \pm 0,33$ & $27,92 \pm 1,55^{* * *}$ & $20,12 \pm 2,20^{* * *}$ \\
\hline
\end{tabular}

Table 4: TThe content of lymphocytes expressing activation receptors of activation apoptosis in the peripheral blood in patients with various forms of atopic diseases, $\mathrm{X} \pm \mathrm{m}$.

\begin{tabular}{|c|c|c|c|}
\hline Antigens markers & $\begin{array}{c}\text { Healthy } \\
\text { donors }\end{array}$ & $\begin{array}{c}\text { Atopic bronchial } \\
\text { asthma }\end{array}$ & $\begin{array}{c}\text { Atopic } \\
\text { dermatitis }\end{array}$ \\
\hline $\mathrm{CD}^{+} 5^{+}$ & $4,42 \pm 0,20$ & $3,74 \pm 0,68$ & $3,60 \pm 0,81$ \\
\hline $\mathrm{CD} 178^{+}$(CD95L) & $5,30 \pm 0,96$ & $16,66 \pm 2,44^{* * *}$ & -- \\
\hline
\end{tabular}

For atopic diseases during the period of exacerbation is characteristic (Tables 1-4):

1. decrease in the total content of T-lymphocytes,

2. an increase in the number of $\mathrm{CD}_{56} 6^{+}$lymphocytes (was investigated in patients with atopic bronchial asthma),

3. increase in the blood levels of all subpopulations of B-lymphocytes,

4. an increase in the number of lymphocytes expressing surface markers of both early (CD25 and CD71) and late (HLADR) activation,

5. decrease in the number of cells expressing the receptor for activation apoptosis CD95

According to our data, a pronounced feature of the immunopathogenesis of inflammation in allergic (atopic) diseases is a clear mismatch between the high level of expression of early activation antigens (CD25 and CD71) on the one hand and the weakened expression of the receptor of triggering apoptosis triggering (CD95) on the other. These data suggest that in atopic diseases there is a violation of lymphocytes activation apoptosis. 
This discrepancy in the expression of these activation markers causes an increase in the number of mature cell forms (HLA-DR antigen). In general, the activation process in the immune system during atopy is aimed at the formation of plasma cells capable of developing intensive synthesis of IgE, as evidenced by a twofold increase in the number of plasma cell precursors (CD38 ${ }^{+}$cells). Fas/ FasL deficiency, which causes impaired activation of lymphocyte apoptosis, was found in the study of atopic dermatitis [12]. The violation of activation apoptosis of lymphocytes during atopy obviously has a definite reason, which in our opinion consists in the presence of miR-23a/b micro RNA in the atopic patients, which can inhibit the synthesis of CD95 receptor subunits [13]. Invariant NKT lymphocytes (iNKT) localized in the epithelium can serve as a probable source of this micro RNA. The results of the study show that the main link in the immunopathogenesis of atopy is uncompensated B-cell activation induced, apparently, by a minor subpopulation of NKT cells. Their transition from the mucous membranes to the blood supports the activation of lymphocytes, and the presence of an allergen causes excessive generation of oxygen radicals, tissue damage, a change in the composition of membrane lipids and a violation of the activation of lymphocytes apoptosis.

\section{Conclusion}

Thus, there are symptoms of apoptosis inhibition in patients with severe clinical manifestations of atopy (atopic bronchial asthma and atopic dermatitis), which can play an important role in maintaining prolonged activation of the immune system and many years of sensitization that is associated with the hyperproduction of IgE. Our results strongly suggest that atopic diseases have not only various clinical manifestations, but also various mechanisms of the immune system disorders. However, the leading mechanism, characteristic for both studied atopic diseases is a violation of Fas/ FasL interaction, which causes the weakening of the activation lymphocytes apoptosis. Violation of activation of lymphocytes apoptosis in patients with atopy increases the lifetime of plasma cells and hyperproduction of IgE explain. It can be assumed that micro RNA miR-23a/b is responsible for the inhibition of synthesis and low levels of expression of the activation apoptosis receptors. Source of this micro RNA is unknown, but we believe that invariant NKT lymphocytes are responsible for the production of this molecule.

\section{Conflict of Interest}

The authors declare no apparent or potential conflicts of interest related to the publication of this article.

\section{Acknowledgment}

The authors of this study show appreciation all the employees of the Department of Pathophysiology and Clinical Pathophysiology for splendid support in the preparation of this manuscript.

\section{References}

1. Nagafuku M, Okuyama K, Onimaru Y, Suzuki A, Odagiri Y, et al. (2012) CD4 and CD8 T cells require different membrane gangliosides for activation. Proc Natl Acad Sci USA 109(6): 336-342.

2. Albacker LA, Chaudhary V, Chang YJ, Kim HY, Chuang YT, et al. (2013) Invariant natural killer $\mathrm{T}$ cells recognize a fungal glycosphingolipid that can induce airway hyperreactivity. Nat Med 19(10): 1297-1304.

3. Inokuchi J, Nagafuku M, Ohno I, Suzuki A (2015) Distinct selectivity of gangliosides required for $\mathrm{CD}^{+} \mathrm{T}$ and $\mathrm{CD}^{+} \mathrm{T}$ cell activation. Biochim Biophys Acta 1851(1): 98-106.

4. Poryadin GV, Salmasi JM, Kazimirskiy AN (2010) A method for evaluating the effectiveness of the treatment of bronchial asthma. Patent for invention №2389023, 6S (in Russian).

5. Wei H, Zhang J, Xiao W, Feng J, Sun R, et al. (2005) Involvement of human natural killer cells in asthma pathogenesis: Natural killer 2 cells in type 2 cytokine predominance. J Allergy Clin Immunol 115(4): 841-847.

6. Poryadin GV, Zhuravleva NE, Salmasi JM, Kazimirskiy AN, Semenova LY, et al. (2002) Immunological mechanisms of recovery from an acute stage in patients with atopic bronchial asthma. Russ J Immunol 7(3): 259-264.

7. Salmasi JM, Poryadin GV, Alieva ZO, Kazimirskiy AN (2004) Characterization of surface blood lymphocyte receptors in patients with atopic dermatitis. Allergology immunol 5(1): 54-70.

8. Kazimirsky AN, Salmasi JM, Poryadin GV, Svitich OA, Bragvadze BG, et al. (2019) The role of epithelial cells in atopy pathogenesis. Bulletin Siberian Med 18(1): 201-210.

9. Fabian E, Pölöskey P, Kósa L, Elmadfa I, Réthy LA (2011) Activities of antioxidant enzymes in relation to oxidative and nitrosative challenges in childhood asthma. J Asthma 48(4): 351-357.

10. Ahmad A, Shameem M, Husain Q (2012) Relation of oxidant-antioxidant imbalance with disease progression in patients with asthma. Ann Thorac Med 7(4): 226-232.

11. Fatani SH (2014) Biomarkers of oxidative stress in acute and chronic bronchial asthma. J Asthma 51(6): 578-584.

12. Bień K, Żmigrodzka M, Orłowski P, Fruba A, Szymański Ł, et al. (2017) Involvement of Fas/FasL pathway in the murine model of atopic dermatitis. Inflamm Res 66(8): 679-690.

13. Li B, Sun M, Gao F, Liu W, Yang Y, et al. (2013) Up-regulated expression of miR-23a/b targeted the pro-apoptotic Fas in radiation-induced thymic lymphoma. Cell Physiol Biochem 32(6): 1729-1740. 
ISSN: 2574-1241

DOI: 10.26717/BJSTR.2019.22.003714

Kazimirskii AN. Biomed J Sci \& Tech Res

(C) (1) This work is licensed under Creative

Submission Link: https://biomedres.us/submit-manuscript.php

\begin{tabular}{ll} 
BIOMEDICAL & \multicolumn{1}{c}{ Assets of Publishing with us } \\
RESEARCHES & - Global archiving of articles \\
- Immediate, unrestricted online access \\
- Rigorous Peer Review Process \\
https://biomedres.us/
\end{tabular}

